\title{
多自由度球面アクチュエータの出カトルク計算における解析精度向上
}

\section{Improvement of Analysis Accuracy in Torque Calculation of Multi-Degree-of-Freedom Spherical Actuators}

\author{
房安＼cjkstart浩嗣*1(正員), 平田 勝弘 ${ }^{* 2}$ (正員), 新口＼cjkstart昇 ${ }^{* 2}$ (正員), 高原 一晶*2(学生員)
}

Hirotsugu FUSAYASU (Mem.), Katsuhiro HIRATA (Mem.), Noboru NIGUCHI (Mem.), Kazuaki TAKAHARA (Stu. Mem.)

\begin{abstract}
Multi-degree-of-freedom (multi-DOF) spherical actuators have been developed for the fields of robotics and industrial machinery. We have proposed an outer rotor type three-DOF spherical actuator that can realize a high torque density. Its input current of each coil is calculated using the torque generation equation based on the torque constant matrix. Although a control method to calculate the current value has already been proposed, the analysis accuracy of the torque model is not sufficiently examined for a precision robot that requires the positioning accuracy of about $0.1 \mathrm{~mm}$. In this paper, for the purpose of applying our three-DOF spherical actuator to such a precision robot, we investigated the factors that affect the analysis accuracy of a dynamic analysis method and improved the analysis accuracy.
\end{abstract}

Keywords: multi-degree-of-freedom, spherical actuator, industrial robots, torque constant map, finite element method.

(2020 年 11 月 16 日受付, 2021 年 3 月 15 日再受付)

\section{1 緒言}

近年，工作機械をはじめとする多くの機械が多軸化， 多自由度化しており，それらの装置では，多自由度の 動作を実現するために, その自由度に応じて 1 自由度 アクチュエータを組み合わせている[1]。エンドエフェ クタ側のアクチュエータの質量がベース付近のアクチ ユエータの負荷となるため, アクチュエータが大型化 する傾向にあり, 力制御等における問題が指摘されて いる[2]。また, 各アクチュエータの位置決め誤差の累 積により, ロボット先端の位置決め精度が低下すると いう課題も存在する。これに対して, 球面駆動可能な アクチュエータを用いることで，機構小型化による前 述の制御問題の解決, および各自由度の回転軸が一点 で交わることでの制御簡素化による高速化，高度化が 可能となる。さらに, 各アクチュエータの位置決め誤 差の累積がなく, 高精度の位置決めが期待できる。こ れらの理由から, 球面駆動可能なアクチュエータは, 産業用ロボット等の分野, 中でも, 人の手での直接操 作が困難な微細作業や危険作業等を置き換えるロボッ トへの応用が期待されている。

電磁力を利用した多自由度球面アクチュエータは, 連絡先： 房安 浩嗣, テ571-8506 門真市門真 1006, パナ ソニック（株）CN S 社 生産技術センター, e-mail: fusayasu.hirotsugu@jp.panasonic.com *1 パナソニック ${ }^{* 2}$ 大阪大学
同期モータやステッピングモータ等の様々な駆動原理 を利用したアクチュエータが報告されており, 球面同 期アクチュエータは，任意軸まわりトルクを制御可能 なトルク発生式が提案されており，その制御性の高さ から多くの研究機関が開発に取り組んでいる[3-8]。

これまで，筆者らは，高トルク密度実現可能なアウ ターロータ型の 3 自由度球面アクチュエータの開発を 行っており，トルク定数行列をもとにトルク発生式を 用いて各コイルの入力電流值を算出する制御方法を提 案しているが, $0.1 \mathrm{~mm}$ 程度の位置決め精度を必要とす る微細作業ロボットへの適用に対しては，トルクモデ ルの解析精度の検討が不十分である $[9,10]$ 。

そこで本稿では，トルク発生式を用いたトルクモデ ルを筆者らが提案してきた球面同期アクチュエータに 適用し，トルクの解析精度に影響を与える因子を検討 し, 解析精度改善に関する検討を行ったので報告する。

\section{2 球面アクチュエータの構造と動作原理}

\section{1 アクチュエータ構造}

本稿で扱う 3 自由度の駆動が可能なアウターロータ 型球面同期アクチュエータは, Fig. 1 に示すように, 球 状の可動子内面に緯度, 経度方向に極が切り替わるよ うに球殼状の永久磁石を配置し, 固定子に複数のコイ ルを配置している。アウターロータ型は可動子を外側 に持ち, 電磁力が発生するエアギャップを外側に配置 


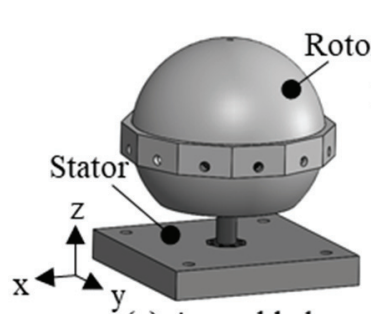

(a) Assembled

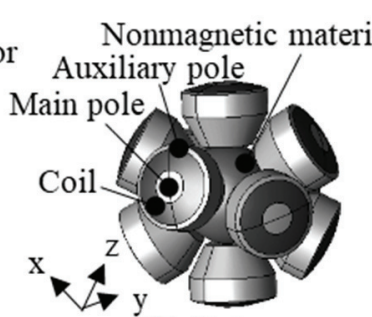

(b) Stator

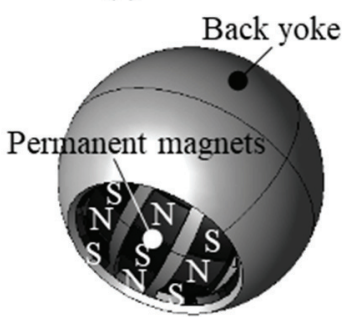

(c) Rotor

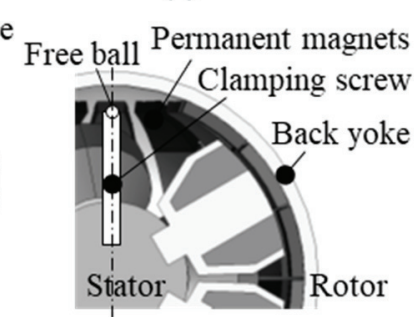

(d) Support structure of outer rotor
Fig. 1 Structure of spherical actuator (full model).

Table 1 Specification of spherical actuator.

\begin{tabular}{|c|c|c|}
\hline \multicolumn{2}{|c|}{ Diameter $[\mathrm{mm}]$} & 97.0 \\
\hline \multicolumn{2}{|c|}{ Thickness of permanent magnets [mm] } & 3.0 \\
\hline \multicolumn{2}{|c|}{ Air gap length $[\mathrm{mm}]$} & 0.7 \\
\hline \multicolumn{2}{|c|}{ Residual magnetic flux density [T] } & 0.68 \\
\hline \multicolumn{2}{|c|}{ Number of phases } & 5 \\
\hline \multicolumn{2}{|c|}{ Number of coil turns } & 180 \\
\hline \multirow{2}{*}{ Movable range [deg] } & $\mathrm{x}$ and $\mathrm{y}$-axis & 40 \\
\hline & z-axis & 360 \\
\hline
\end{tabular}

できるため, 高トルク化が期待できる。一方で, 可動 子が外側にあることから球面軸受を用いて可動子を支 持することが困難であり, ジンバル機構による支持は システム全体の大型化につながる。そこで, Fig. 1(d)の ように先端が自由に回転するクランピングスクリュー で可動子内側を直接支持する構造としている。駆動時 は可動子と同期するようにコイルに多相の電圧を印加 し, 多自由度の回転を実現している。なお，コイルに 印加する電圧の相数はアクチュエータによって異なり, 4 相励磁から 96 相励磁まで報告されている[11, 12]。

本稿では，少相化と高トルク化の両立が可能な球面 アクチュエータとして, 文献[13]により提案した補極 を有する磁気回路独立磁極モデル構造であるクラウン ポール型モデル (以下, $\mathrm{CP}$ 型モデル) を用いて, トル クモデルの解析精度の検討を行う。アクチュエータ仕 様を Table 1 に示寸。球状の可動子には球款状の永久磁 石が緯度 $\theta$ 方向に 22.5 度間隔, 経度 $\varphi$ 方向に 30 度間隔 で極が切り替わるよう配置されている。固定子は, 原 点対称の位置関係にある 2 本の磁極を一対とした磁極
対で構成される。磁極対は，コイルと軟磁性体の鉄心

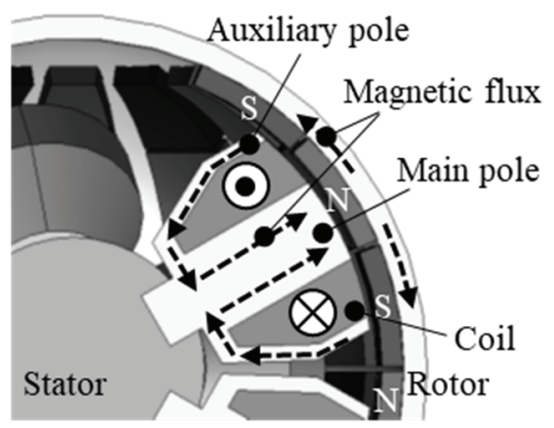

Fig. 2 Flow of magnetic flux.

でできており，CP型モデルの特徵として，Fig. 2 に示 すように主極鉄心の周囲に巻いたコイルを覆うように 補極が追加されている。これにより, 磁束は主極鉄心 から可動子のバックヨークを通り, 補極を通ってルー プするので，主極鉄心に加え補極鉄心でもトルクを発 生可能であり, 高トルク化が可能な構造である。Fig. 1 に示す固定子には，10 本の磁極（5 本の磁極対）が配 置されている。磁極対を構成する 2 本の磁極には同相 の電流を入力するため, 制御電流の相数は磁極数の半 数となり, 5 相となる。

\section{2 トルク発生式}

本稿で用いるトルク発生式について述べる。ここで, 各コイルで生成された磁界は他のコイルで生成された 磁界に影響を及ぼさず，独立にアクチュエータのトル クに寄与すると仮定すると, 多自由度の球面同期アク チュエータのトルク発生式は次式で表される[14, 15]。

$$
\begin{aligned}
{\left[\begin{array}{c}
T_{x} \\
T_{y} \\
T_{z}
\end{array}\right] } & {\left[\begin{array}{llll}
K_{m x}\left(p_{1}\right) & K_{m x}\left(p_{2}\right) & \cdots & K_{m x}\left(p_{n}\right) \\
K_{m y}\left(p_{1}\right) & K_{m y}\left(p_{2}\right) & \cdots & K_{m y}\left(p_{n}\right) \\
K_{m z}\left(p_{1}\right) & K_{m z}\left(p_{2}\right) & \cdots & K_{m z}\left(p_{n}\right)
\end{array}\right]\left[\begin{array}{c}
i_{1} \\
i_{2} \\
\vdots \\
i_{n}
\end{array}\right] } \\
& +\left[\begin{array}{l}
T_{\operatorname{cog} x}\left(p_{1}\right)+T_{\operatorname{cog} x}\left(p_{2}\right)+\cdots+T_{\operatorname{cog} x}\left(p_{n}\right) \\
T_{\operatorname{cog} y}\left(p_{1}\right)+T_{\operatorname{cog} y}\left(p_{2}\right)+\cdots+T_{\operatorname{cog} y}\left(p_{n}\right) \\
T_{\operatorname{cog} z}\left(p_{1}\right)+T_{\operatorname{cog} z}\left(p_{2}\right)+\cdots+T_{\operatorname{cog} x}\left(p_{n}\right)
\end{array}\right] \\
& =\boldsymbol{K}_{m} \boldsymbol{i}+\boldsymbol{T}_{\operatorname{cog}}
\end{aligned}
$$

ここで， $T_{x}, T_{y}, T_{z}$ はそれぞれ $\mathrm{x}, \mathrm{y}, \mathrm{z}$ 軸まわりの出 カトルク, $p_{n}$ は可動子座標系での各コイルの位置を示 し, $K_{m x}\left(p_{n}\right), K_{m y}\left(p_{n}\right), K_{m z}\left(p_{n}\right)$ はそれぞれ x, $\mathrm{y}, \mathrm{z}$ 軸まわりの各コイルにおけるマグネットトルク定数, $i_{1}, i_{2}, \ldots, i_{n}$ は各相のコイル電流, $T_{\operatorname{cog} x}\left(p_{n}\right), T_{c o g y}$ $\left(p_{n}\right), T_{\operatorname{cog} z}\left(p_{n}\right)$ はそれぞれ $\mathrm{x}, \mathrm{y}, \mathrm{z}$ 軸まわりの各磁 


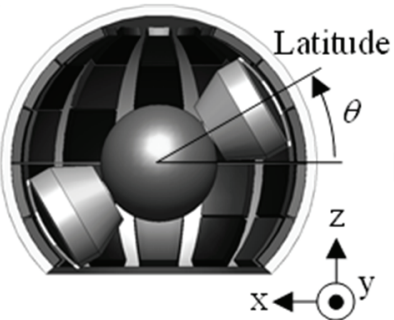

(a) Latitudinal direction

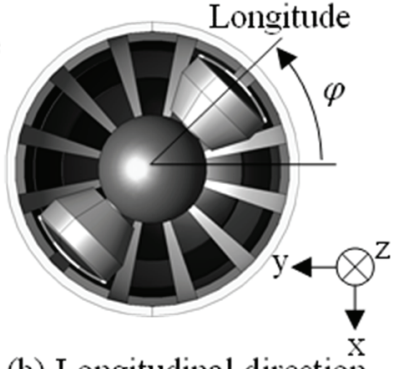

(b) Longitudinal direction
Fig. 3 Simple pole model.

極におけるコギングトルクを示す。また， $\boldsymbol{K}_{\boldsymbol{m}}$ はマグネ ットトルク定数行列， $T_{\operatorname{cog}}$ はコギングトルクベクトル である。式(1)の右辺第 1 項は電流トルク, 右辺第 2 項 はコギングトルクであり, 出力トルクはこの二つのト ルクの和で表される。

球面アクチュエータのトルクは, Fig. 3 に示すよう な簡易磁極モデルが各姿勢におけるコイル位置 $p_{n}$ で 発生するトルクを足し合わせることによって式(1)か ら得られる。簡易磁極モデルを緯度 $\theta$ 方向に $\Delta \theta$ 刻み, 経 度 $\varphi$ 方向に $\Delta \varphi$ 刻みで回転させて, その各姿勢に対して 3 次元有限要素法を用いた磁界解析を行い, 次式によ り，マグネットトルク定数行列 $\boldsymbol{K}_{\boldsymbol{m}}\left(\boldsymbol{p}_{n}\right)$ とコギングト ルクベクトル $T_{\operatorname{cog}}\left(p_{n}\right)$ を算出することで, トルク定数 マップが計算できる。

$$
\begin{gathered}
\boldsymbol{K}_{\boldsymbol{m}}\left(p_{n}\right)=\left[\begin{array}{l}
K_{m x}\left(p_{n}\right) \\
K_{m y}\left(p_{n}\right) \\
K_{m z}\left(p_{n}\right)
\end{array}\right]=\boldsymbol{T}\left(p_{n}, 1 \mathrm{~A}\right)-\boldsymbol{T}\left(p_{n}, 0 \mathrm{~A}\right) \\
\boldsymbol{T}_{\boldsymbol{c o g}}\left(p_{n}\right)=\left[\begin{array}{l}
T_{\operatorname{cog} x}\left(p_{n}\right) \\
T_{\operatorname{cog} y}\left(p_{n}\right) \\
T_{\operatorname{cog} z}\left(p_{n}\right)
\end{array}\right]=\boldsymbol{T}\left(p_{n}, 0 \mathrm{~A}\right)
\end{gathered}
$$

ここで， $\boldsymbol{T}$ は磁界解析により得られた簡易磁極モデル に働くトルクであり, $p_{n}$ は簡易磁極モデルの可動子座 標系での位置，0A，1A はそれぞれコイルに流れる電 流である。これらのトルク定数行列は，あらかじめ設 定した磁極位置の $\mathrm{x}, \mathrm{y}, \mathrm{z}$ 軸まわりのトルク定数を記 したトルク定数マップとなり，任意の可動子姿勢に対 する磁極位置で必要なトルク定数は, トルク定数マッ プから磁極位置に応じた值を参照することで求まる。 トルク定数マップをフルモデルの解析結果から求めよ うとすると， 3 自由度の球面アクチュエータの任意の 回転を表現するには, 磁極と永久磁石との位置関係に
対称性がないため, 緯度 $\theta$ 方向, 経度 $\varphi$ 方向ともに可動 領域全体にわたる解析を行う必要があるが，一対の磁 極対からなる簡易磁極モデルを用いる場合, 緯度 $\theta$ 方 向に $1 / 2$, 経度 $\varphi$ 方向に 1 電気角分の解析を行うことで, モデルの対称性を利用して可動領域全体のトルク定数 マップを算出することができる。

\section{3 出力トルクの解析精度}

Fig. 1〜3 の 3 自由度球面アクチュエータを用い, 出 カトルクの解析精度を検証する。任意姿勢において目 標トルクを出力するための各相の電流值は, 式(1)を用 いることで計算できる。可動子を回転させて，各姿勢 で目標トルクを出力する各相の電流值を式(1)から計 算し，その電流值を Fig. 1 のフルモデルに入力し， 3 次 元有限要素法による磁界解析により出力トルクを算出 する。目標トルクに対する出力トルクを比較すること で，本解析法の解析精度を検証する。

Fig. 4 にトルク定数マップ解析を行う簡易磁極モデ ルとトルク解析を行うフルモデルの磁界解析における 要素分割図を示し，Table 2 に解析諸元を示す。両モデ ルとも, 磁極部分の要素サイズを $1 \mathrm{~mm}$ 程度に設定し たが, Fig. 4 に示すように, 簡易磁極モデルは磁極対が 1 対のみであるためフルモデルとは要素分割が異なる。 1 ステップ当たりの解析時間は，簡易磁極モデルを用 いたトルク定数マップ解析が約 2 分, フルモデルを用 いたトルク解析が約 3 分である。出力トルクの解析精 度への影響が大きいトルク定数マップの分解能は, 緯

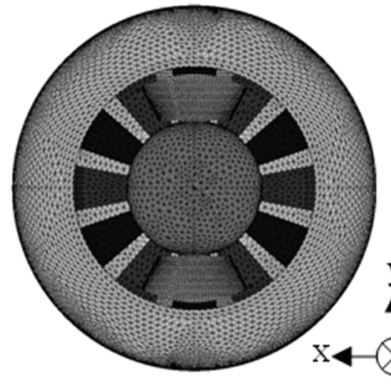

(a) Simple pole model

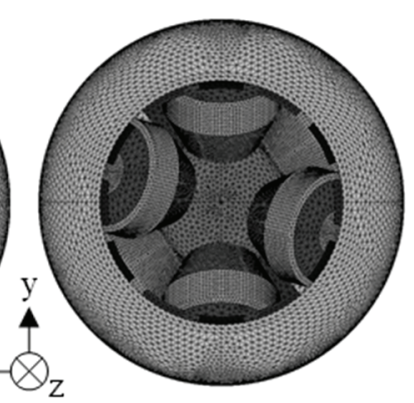

(b) Full model
Fig. 4 Finite-element subdivisions except to air.

Table 2 Discretization data.

\begin{tabular}{|c|c|c|}
\hline Model & Simple pole & Full \\
\hline Number of elements & $1,013,536$ & $1,415,804$ \\
\hline Number of nodes & 200,640 & 268,670 \\
\hline Number of steps & $\begin{array}{c}891 \times 2 \text { current } \\
\text { condition }\end{array}$ & 41 \\
\hline CPU time [h] & 57 & 2.1 \\
\hline
\end{tabular}

Used computer : Intel Xeon Gold 5122 x 2 (3.6GHz), 4 parallel 


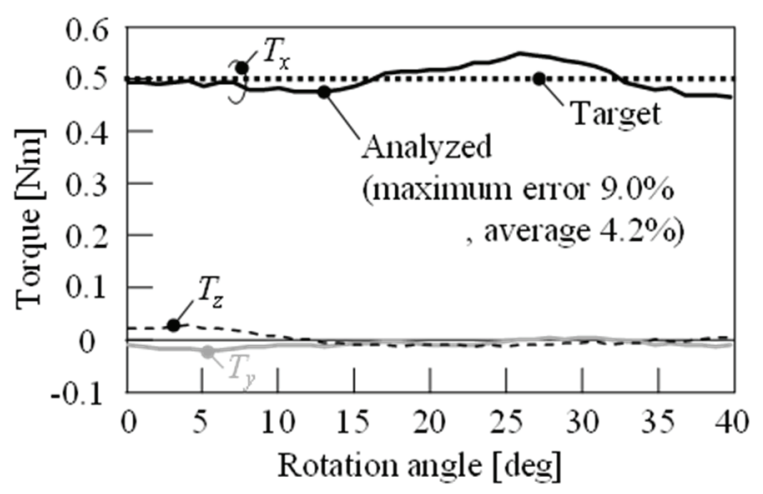

Fig. 5 Static analysis result.

度 $\theta$ 方向に 1.1 度, 経度 $\varphi$ 方向に 1.5 度とし, $0 \mathrm{~A}$ と $1 \mathrm{~A}$ の電流值に対してそれぞれ 891 ステップの解析を行っ てトルク定数マップを算出した[9]。検証は，可動子を $\mathrm{x}$ 軸のまわりに $0 \sim 40$ 度の範囲で 1 度ごとに回転させ 41 ステップの解析を行い, その各姿勢で目標トルク $T_{x}$ $=0.5 \mathrm{Nm}$ に対する出力トルクを比較する。Fig. 5 に出力 トルクの解析結果を示寸。Fig. 5 より $\mathrm{x}$ 軸まわりの出 カトルク $T_{x}$ の解析結果は, 目標トルクに対して平均 $4.2 \%$ 、最大で $9 \%$ の誤差があり, $0.1 \mathrm{~mm}$ 程度の位置決 め精度を必要とする微細作業ロボットへの適用を考え ると, 解析精度の向上が必要である。

\section{3 出カトルクの解析精度向上検討}

\section{1 出力トルクの解析誤差要因}

Fig. 5 に示した出力トルクの解析誤差の要因を考察 する。出力トルクは式(1)より, 電流卜ルクとコギング トルクの和で表されることから, Fig. 5 の出力トルク の解析結果を, 電流トルクとコギングトルクの成分に 分解して比較することで, 解析誤差の要因を考察する。 ここでは, 代表して $\mathrm{x}$ 軸のまわりのトルク成分により 検討を行う。Fig. 6 に電流トルク, Fig. 7 にコギングト ルクを示す。Fig. 6 では，式(1)のトルク発生式におけ る右辺第 1 項の電流トルクを破線で示し，フルモデル の 3 次元有限要素法による出力トルクの解析結果を実 線で示す。Fig. 7 では, 式(1)右辺第 2 項のコギングト ルクトルクを破線で示し，フルモデルの解析結果を実 線で示す。Fig. 6 より, 電流トルクはトルク発生式とフ ルモデルの解析結果で良く一致しており, その差は 1\%以下である。一方, Fig. 7 に示寸コギングトルクは, トルク発生式とフルモデルの解析結果で差があり, そ の差は約 $6 \%$ フルモデルの解析結果が大きくなってい る。この結果より, Fig. 5 に示した出力トルクの解析誤

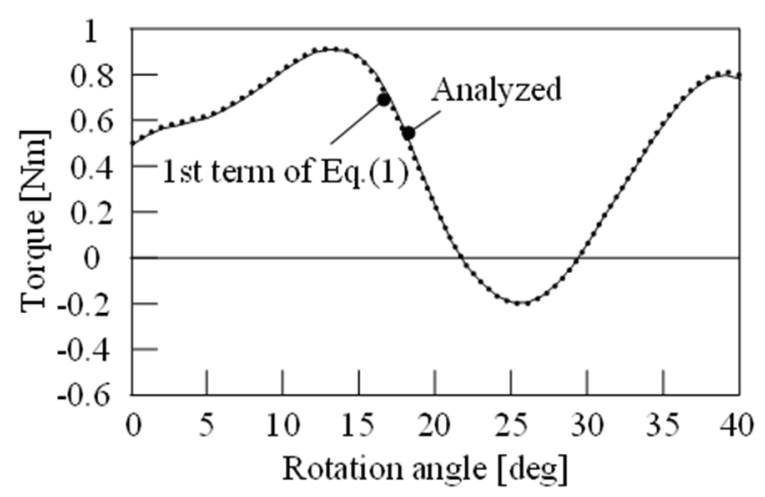

Fig. 6 Comparison of current torque.

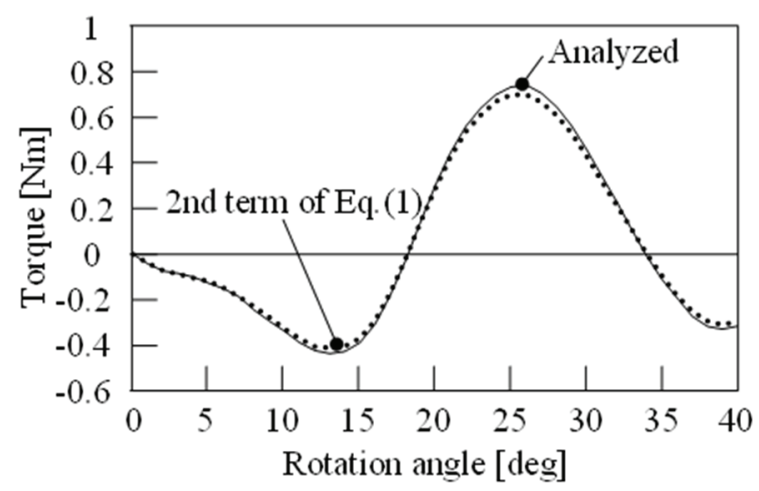

Fig. 7 Comparison of cogging torque.

差の要因は，コギングトルクの解析精度の影響が支配 的であることがわかる。

\section{2 コギングトルク計算の考察}

Fig. 7 に示したコギングトルク計算におけるトルク 発生式とフルモデルの解析結果の差の要因を考察する。 トルク発生式のコギングトルクベクトルは, Fig. 3 の 簡易磁極モデルの磁界解析結果を使っており, Fig. 1 の フルモデルによる解析と, 以下の 2 点が異なる。第 1 の相違点は, Fig. 4 に示したように要素分割が異なる 点であり, 第 2 の相違点は, 簡易磁極モデルでは影響 の小さかった隣接磁極の影響がフルモデルでは大きく なる点である。

第 1 の相違点である要素分割の影響を検討する。Fig. 8 (a) に, 可動子を $\mathrm{x}$ 軸のまわりに $0 \sim 40$ 度の範囲で 1 度ごとに回転させ，その各姿勢で求めた $\mathrm{x}$ 軸のまわり のコギングトルクを示し, Fig. 8 (b) に，比較した $2 つ$ の要素分割のコギングトルクの差を示す。Fig. 8(a) の 灰色の破線は，フルモデルの要素分割（FM）を用いた 結果であり，黒色の実線は簡易磁極モデルの要素分割

（SP）を用いた結果である。Fig. 8 より，フルモデル の要素分割と簡易磁極モデルの要素分割の結果は良く 


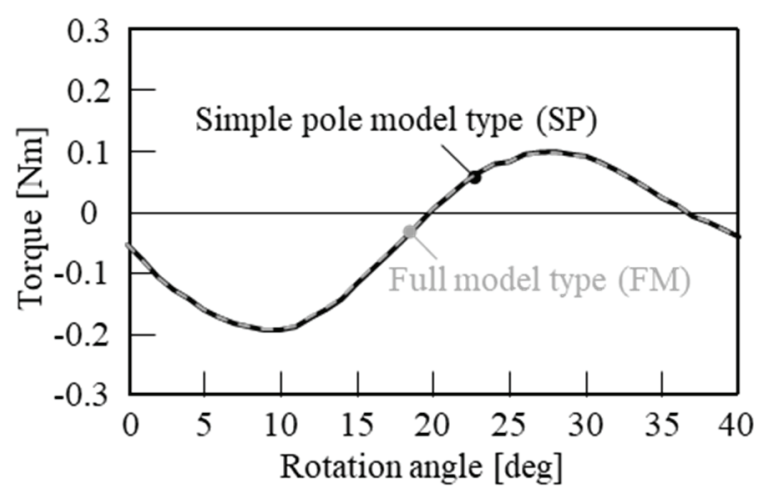

(a) cogging torque around $\mathrm{x}$ axis

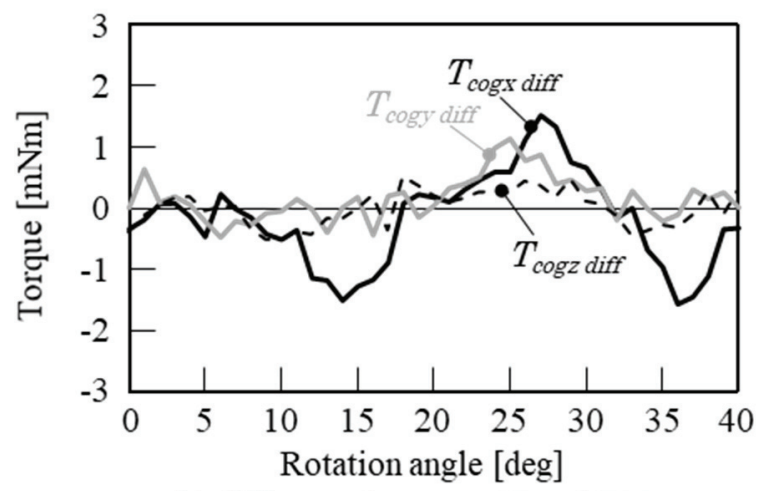

(b) difference between SP and FM

Fig. 8 Comparison of cogging torque by the difference of mesh division.

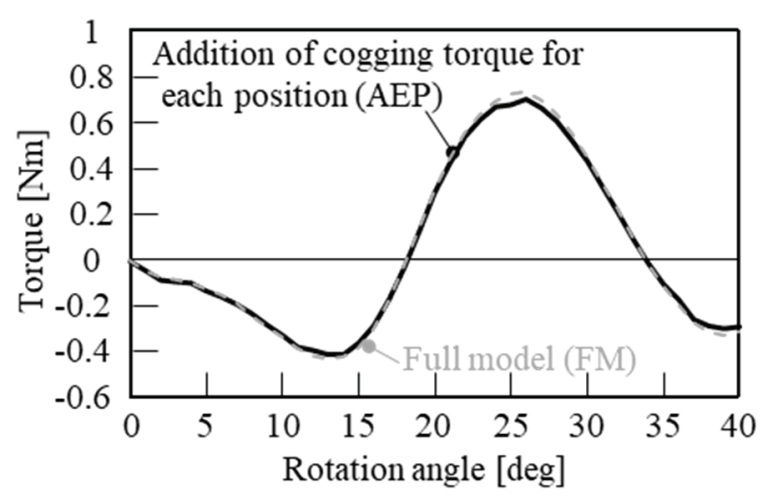

(a) cogging torque around $\mathrm{x}$ axis

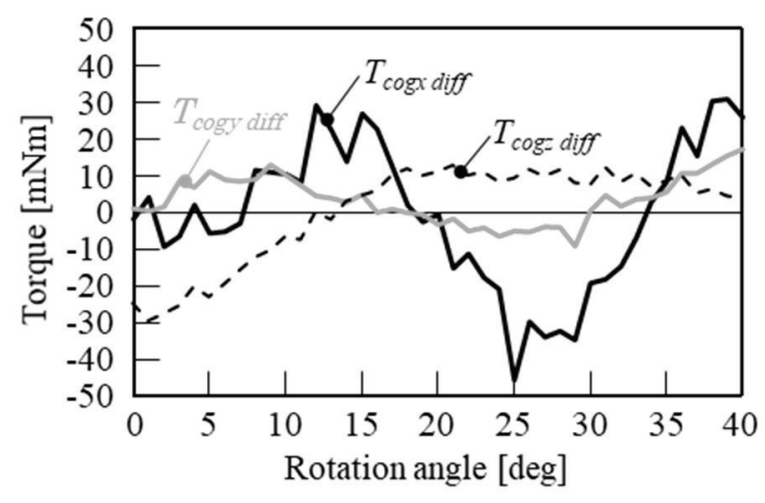

(b) difference between AEP and FM

Fig. 9 Effect of adjacent magnetic poles.
一致しており、その差は $1 \%$ 以下の $2 \mathrm{mNm}$ 以下であ る。このことから，本解析モデルは十分に細かい要素 分割となっており，コギングトルクの差は要素分割の 差ではないことがわかる。

次に，第 2 の相違点である隣接磁極の影響を検討寸 る。 5 本の磁極対からなるフルモデルにおいて，それ ぞれの磁極対のみをモデル化した解析を行い，出力卜 ルクを重㸚合わすことで隣接磁極の影響をなくしたモ デルとフルモデルを比較する。Fig.9(a) に，可動子を x軸のまわりに 0 40度の範囲で1度ごとに回転させ, その各姿勢で求めた $\mathrm{x}$ 軸のまわりのコギングトルクを 示す。灰色の破線はフルモデル (FM)，黒色の実線は 上述の隣接磁極の影響をなくしたモデル (AEP) の結 果である。Fig. 9(b) に，AEP と FM のコギングトルク の差を示す。Fig. 9 より，隣接磁極の有無によりコギン グトルクの解析結果の差は約 $8 \%$ の $50 \mathrm{mNm}$ 程度ある ことがわかる。このことから，Fig. 5 に示した出力トル クの解析誤差の要因として, 本解析法の各コイルの電 流計算において，コギングトルクの隣接磁極の影響を 考慮していないことが支配的であると考えられる。

\section{3 コギングトルク誤差を考慮した電流計算}

トルク定数行列をもとにトルク発生式を用いて各 コイルの入力電流值を算出する本解析法において，(1) 〜(3)式で求めるトルク定数マップのコギングトルク の隣接磁極影響を考慮する方法を検討した。Fig. 7 の 結果より，フルモデルのコギングトルクは，トルク定 数マップから算出するコギングトルクに比べて約 $6 \%$ 大きいことから，トルク定数マップのコギングトルク が過小評価となっていると考えられるため，トルク定 数マップのコギングトルクの補正を考えた。Fig. 10 に, トルク定数マップのコギングトルクを $6 \%$ 補正した結

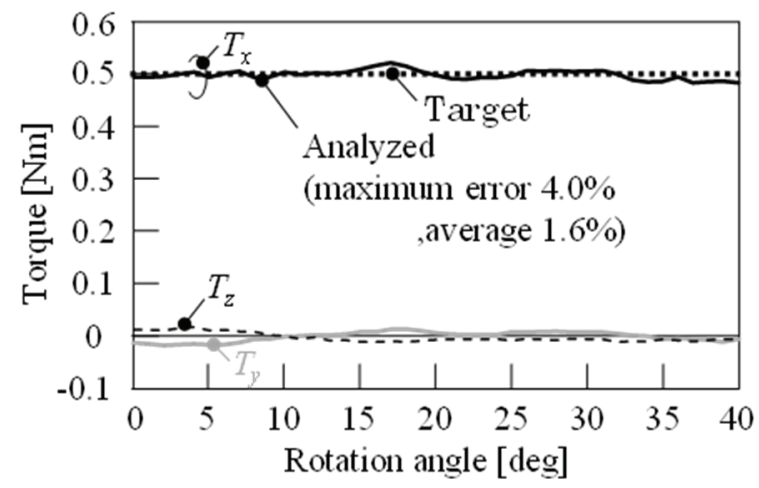

Fig. 10 Analysis result using modified cogging torque. 
果を示す。Fig. 10 より, $\mathrm{x}$ 軸のまわりの出力トルク $T_{x}$ の解析結果は, 平均 $1.6 \%$ (38.1\%低減), 最大で $4 \%$ (44.4\%低減) と，大幅に解析誤差を低減できた。

\section{4 動トルク特性解析}

3 次元有限要素法による磁界解析と次式で示す回転 運動の運動方程式を連成し，可動子の位置をフィード バックする閉ループ制御を行う。

$$
\boldsymbol{T}=J \frac{\mathrm{d}^{2} \theta}{\mathrm{dt}^{2}}+B \frac{\mathrm{d} \theta}{\mathrm{dt}}+K \theta+\tau
$$

ここで，Jは慣性モーメント， $B$ は可動子の周辺媒体（空 気や油など）の粘性減衰係数, $K$ はバネ定数, $\tau$ は摩擦卜 ルクである。

動トルク特性解析における閉ループ制御系を Fig. 11 に示す。制御系は, MATLAB/Simulink で構成し，ここ から得られる各相の電流值 $I_{n}$ を磁界解析モデルの各コ イルの入力とし，可動子に働くトルクを解析する。

Simulink で式(4)の運動方程式を解いて可動子の回転角 度を算出し，フィードバックする。

Fig. 12 に, x 軸のまわりに振幅 15 度, $2 \mathrm{~Hz}$ の正弦波

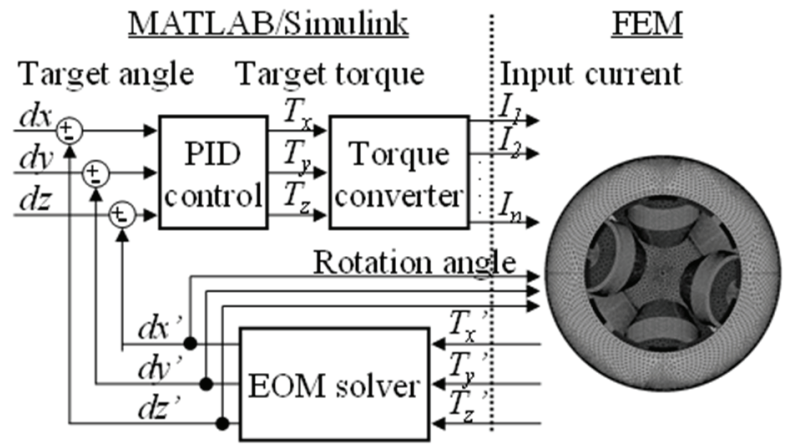

Analyzed angle Analyzed torque

Fig. 11 Control diagram of dynamic analysis.

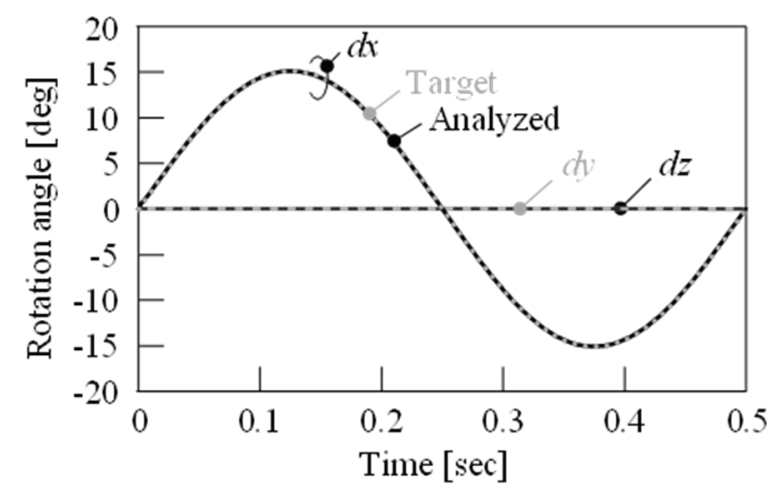

Fig. 12 Result of dynamic analysis.

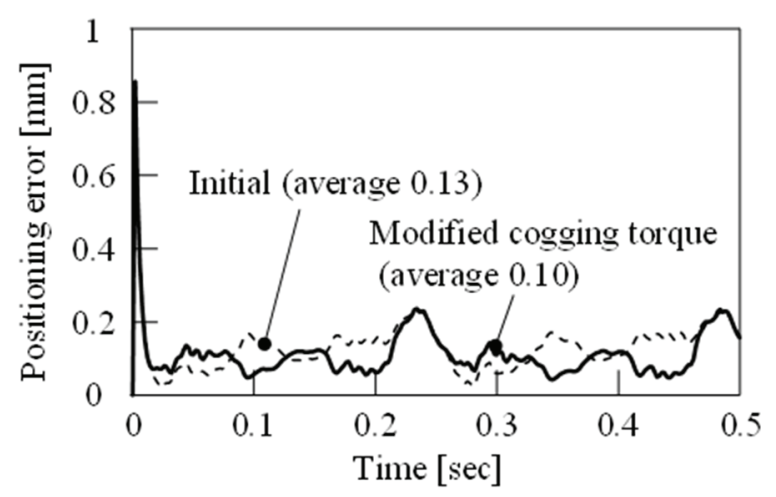

Fig. 13 Comparison of positioning accuracy.

を与えた場合の動トルク特性解析結果を示す。Fig. 12 より, 角度誤差は $1 \%$ 以下で, 良好な結果が得られた。 球面アクチュエータに設置した $200 \mathrm{~mm}$ の長さのアー ム先端の位置決め誤差を Fig. 13 に示す。トルク定数マ ップのコギングトルクを補正する本解析法により，平 均位置決め誤差を $20 \%$ 以上低減となる $0.03 \mathrm{~mm}$ 低減 できた。回転角が 5 度以下となる時間で誤差低減が小 さく, その時間で発生している最大誤差の低減も小さ いが，今回想定している微細作業では 5 度以上回転す るため, $0.1 \mathrm{~mm}$ 程度の位置決め精度を必要とする微細 作業ロボットへの適用に対して, 十分な解析精度が得 られた。なお，回転角が 5 度以下と移動量の小さな作 業を行う場合については，解析時間刻み幅の最適化な どにより解析精度の向上が必要である。

\section{5 結言}

本稿では，アウターロータ型 3 自由度球面同期アク チュエータを用いて, 出力トルクの解析精度に影響を 与える因子を検討し，解析精度の向上を図った。その 結果，トルク発生式を用いたトルクモデルによる本解 析法において，各コイルの電流計算時にコギングトル クの隣接磁極の影響を考慮していないことが誤差発生 の主要因であることがわかった。

そこで、トルク定数マップに対してコギングトルク の隣接磁極影響の補正法を導入し, 出力トルクの解析 精度を 38.1 \%改善し平均誤差 $1.6 \%$ が得られた。さら に， 3 次元有限要素法による磁界解析と MATLAB/Simulink を用いた動トルク特性解析におけ る閉ループ制御系を構築し, 位置決め精度を評価した。 平均位置決め誤差を $20 \%$ 以上低減し， $0.1 \mathrm{~mm}$ 程度の 位置決め精度を必要とする微細作業ロボットへの適用 に対して，十分な解析精度が得られた。 


\section{参考文献}

[1] 武田, パラレルマニピュレータの機構と特性, 日本ロボ ツト学会誌, Vol. 30, No. 2, pp. 124-129, 2012.

[2] H. Asada, T. Kaneda and R. Reddy, Design Concept of DirectDrive Manipulators Using Rare-Earth DC Torque Motors, Proceeding of 11th ISIR, pp. 629-636, 1981.

[3] C. Xia, H. Li and T. Shi, 3-D Magnetic Field and Torque Analysis of a Novel Halbach Array Permanent-Magnet Spherical Motor, IEEE Transactions on Magnetics, Vol. 44, No. 8, pp. 2016-2020, 2008.

[4] H. Son and Kok-Meng Lee, Open-Loop Controller Design and Dynamic Characteristics of a Spherical Wheel Motor, IEEE Transactions on Industrial Electronics, Vol. 57, No. 10, pp. 3475-3482, 2010.

[5] B. van Ninhuijs, J. W. Jansen, B. L. J. Gysen and E. A. Lomonova, Topology Comparison of Slotless Permanent Magnet Semispherical Actuators, IEEE Transactions on Magnetics, Vol. 50, No. 11, 2014.

[6] Y. Sakaidani, K. Hirata, N. Niguchi and S. Maeda, Experimental vertification of feedback control of a 2-DOF spherical actuator, IEEE Transactions on Magnetics, Vol. 50, No. 11, 2014.

[7] A. Bhatia, M. Kumagai and R. Hollis, Six-Stator spherical induction motor for balancing mobile robots, 2015 IEEE International Conference on Robotics and Automation (ICRA), pp. 226-231, 2015.

[8]矢野, 多面体にもとづく球面ステッピングモータの分類, 電気学会研究会資料, IEEJ LD 2009, LD09055, 2009.

[9] 房安, 増山, 平田, 新口, 高原, 多自由度球面アクチュ エータの出力トルク計算における解析精度の検討, 日本 機械学会第 31 回「電磁力関連のダイナミクス」シンポ ジウム, 23A1-4, 2019.

[10] 房安, 増山, 平田, 新口, 高原, 多自由度球面アクチュ エータのトルク計算方法と位置決め精度の関係, 電気学 会リニアドライブ研究会資料, MAG-19-180, MD-19-118, LD-19-084, 2019.

[11] J. Wang, G. W. Jewell and D. Howe, A Novel Spherical Actuator: Design and Control, IEEE Transactions on Magnetics, Vol. 33, No. 5, pp. 4209-4211, 1997.

[12] K. Kahlen, I. Voss, C. Priebe and R. W. De Doncker, Torque Control of a Spherical Machine With Variable Pole Pitch, IEEE Transactions on Power Electronics, Vol. 19, No. 6, pp. 1628-1634, 2004.

[13] 高原, 平田, 新口, 雨堤, 新しい磁極構造を有する少相 3 自由度球面アクチュエータの開発, 日本 AEM 学会 MAGDA コンファレンス, OS8-2, 2018.

[14] 西浦, 平田, 堺谷, 新口, 3 自由度アウターロータ型電 磁球面アクチュエータに関する研究, 電気学会論文誌 D, Vol. 136, No. 3, 2016.

[15] N. Kasashima, K. Ashida, T. Yano, A. Gofuku and M. Shibata, Torque Control Method of an Electromagnetic Spherical Motor Using Torque Map, IEEE/ASME Transactions on Mechatronics, Vol. 21, No. 4, pp. 2050-2060, 2016. 